\title{
Pyrolytic Disintegration of selected Tobacco Constituents and Pyrosynthetic Formation of Aromatic Hydrocarbons from Cleavage Products formed by Pyrolysis*
}

\author{
by Jargen Lam, B. O. Pedersen and T. Thomasen \\ Department of Organic Chemistry, Chemical Institute, University of Aarbus, \\ Aarbss, Denmark
}

\section{SUMMARY}

A rapid pyrolysis technique, combined with gas chromatographic separation and interpretation of mass spectra obtained from the resulting pyrolysis-pyrosynthesis products, has been used in the study of three different compounds present in processed tobacco: $n-\mathrm{C}_{25}$ alkane, neophytadiene and phytol. The compounds are representative for a homologous series of $n$-alkanes and for a series of branched-chain compounds including neophytadiene, phytol, solanesol and esters of solanesol (tobacco constituents).

At temperatures below $600^{\circ} \mathrm{C}$ the pyrolysis in the absence of oxygen, but in a helium flow gives only slight aromatization when $n$-alkanes are treated. For the isoprenoid compounds neophytadiene and phytol aromatization starts between 500 and $600^{\circ} \mathrm{C}$. The products formed tend to develop more-condensed ring structures at increasing temperature, although benzene and toluene are dominating even at temperatures as high as 800 to $900^{\circ} \mathrm{C}$.

Aromatization leading to relatively less methyl substitution results with increasing temperature. Previous pyrolysis work and recent interpretations point to the formation of structures such as acenaphthylene, acenaphthene, cyclopenta $[c d]$ pyrene, 3,4-dihydrocyclopenta[ $c d]$ pyrene and probably similar structures derived from three and four-membered condensed ring structures produced.

\footnotetext{
- Recejved: 23rd March 1984 - accepted: 16th October 1984.
}

\section{ZUSAMMENFASSUNG}

Zur Untersuchung der drei Substanzen $n-\mathrm{C}_{25}$-Alkan, Neophytadien und Phytol, die in verarbeitetem Tabak vorkommen, wurde eine schnelle Pyrolysemethode in Verbindung mit gaschromatographischer Auftrennung und massenspektrometrischer Analyse der Pyrolyse/ Pyrosynthese-Produkte angewendet. Die Substanzen stehen stellvertretend für eine homologe Reihe von n-Alkanen sowie für verzweigte Verbindungen wie Neophytadien, Phytol, Solanesol und Solanesolester (Tabakinhaltsstoffe).

Bei Temperaturen unter $600^{\circ} \mathrm{C}$ führt die Pyrolyse von n-Alkanen im Heliumstrom unter Ausschluß von Sauerstoff nur in geringem Ausmaß zu Aromatisierung. Bei den Isopren-Verbindungen Neophytadien und Phytol beginnt die Aromatisierung bei Temperaturen $z$ wischen $500{ }^{\circ} \mathrm{C}$ und $600^{\circ} \mathrm{C}$. Die Pyrolyseprodukte neigen bei ansteigender Temperatur zur Bildung hōher kondensierter Ringsysteme, obwohl Benzol und Toluol noch bei $800^{\circ} \mathrm{C}$ bis $900^{\circ} \mathrm{C}$ dominieren.

Mit ansteigender Temperatur werden im Verhältnis weniger methylsubstituierte Aromaten gebildet. Frühere Pyrolyseversuche und Interpretationen aus jüngerer Zeit deuten auf die Bildung von Substanzen wie Acenaphthylen, Acenaphthen, Cyclopenta[cd]pyren und 3,4-Dihydrocyclopenta[cd]pyren sowie auf das Entstehen wahrscheinlich strukturell ähnlicher Verbindungen hin, welche sich von Strukturen ableiten, die aus kondensierten Systemen mit drei und vier Ringen bestehen. 


\section{RESUME}

L'examen de trois subatances: $n-C_{25}-2$ lcane, néophytadienne et phytol, que l'on trouve dars le tabac traité industriellement, a eté réalise au moyen d'une méthode de pyrolyae rapide associée l la sépararion par chromatographie en phase gazense te 2 l'analyse par spectrometrie de masse des produits de la proolyse/pyronynthèse. Les substances tuditea représentent une sétrie bomologue de N-alcanes ainsi que des composes a chaine ramifiée tels que néophytadizoe, phytol, solanesol et esters du solanesol (conftizuants du tabac).

Lorsque la température est inférieure ì $600^{\circ} \mathrm{C}$, la pyrolyse de o-alcanes dans un courant d'belium of en l'absence d'oxygène ne conduit qu'z une formation restreinte de carbures aromatiques. Dans le cas des conposés isopretnoides, neophytadizone et phytol, l'aronatisation commence a upe temperature comprise entre soo et $600^{\circ} \mathrm{C}$. Larsque la temperature s'alleve, les produits de la pyrolyse ont tendance a former des combinaisons cycliques plus condensées bien que le benzìne et le toluène dominent encore vers $\mathrm{BO0}-900^{\circ} \mathrm{C}$.

Si l'on fait croitre la température, il se forme proportiongellement moing de composes aromatiques methy\}substitues. Des experiences de pyrolyse realistes preetdemment et des interpretations de date recente atrirent l'aktention sur la formation de substances telles que actnaphtylzoe, actnaphtène, cyclopenta[cd]pytène, dibydro 3,4-cyclopenta[cd]pyrène ainji que do structures vraisemblablement similaires dériveses de szstèmes condensts 2 trois ou quatre boyaux aromatiques.

\section{INTRODUCTION}

Previously (in the period 1953-1956) pyrolysis experimencs wete carried out with dotriacontane $\left[\mathrm{C}_{32} \mathrm{H}_{65}\right.$ ] (named dicetyl) $(1,2)$ and with an unspecified mizture of aliphatic tobaceo hydracarbons isolated from tobacco leaves (2). The experinnents were carried out at various temperatures in agreement with data obtained by measurements of temperatures existing in the combustion zones of cigarestes, cigara, and pipes (3). These and related pyrolysis experimencs deal with the formation of aromatic bydrocarbons (4-11). The presence of polycyclic aromatic bydrocarbons in tobacco smoke indictes that insufficient combustion reactions take place during smoking. It bas been recognized for 2 long period that monocyclic and polycyclic aromatic hydrocarbons are generally formed by incomplete combustion at high temperatures from many orgenic compounds originating from fuel oil, fats, phytosterols, tobaceo leaves and other orgaric materials.

The aim of the present researeb is to study the product resulting from pyrolysis of single compounds, isolable from tobacco leaves, the pyralysis being carried ous at warious temperatures. The compounds are of the unbranched, normal alkane cype and of a branched isoprenoid type.
As the occurrence of botb normal alkanes and jsoprenoid compounds is widespread in plants and in fuel oil the results of the prolysis may be of interest beyond the field of tobacco research. Normal alkanes are present in the aerial parts of most plants. Phytol is a part of chlorophyll bound as an ester. Neophytadiene may be formed from phytol by an enzyrotic elimination procedure (12).

Normal $C_{25}$ alkane, phytol and neophytadiene have been chosen for the pyrolysis experiments as they all occur in tobacco leaves. Although the three compounds are representative examples from arcure, many other naturally occurring componnds may be expected to be converted into aromatic hydrocarbons under similar pyrolytic conditions. Thus, for jostance fatcy acids often occur in great amounts is fats from plants and in animal tissues. They contain aliphatic hydrocarbon chains, bence they should also be expected to form aromatic bydrocarbons by pyrolyais as bigh temperatures.

\section{INSTRUMENTS AND EXPERIMENTAL}

A laboratory-built microhuragee of a similar type to the one described by Larter, Sollit and Donglas (13) was conoected to a GC-MS syatem consisting of a VG-Mictomass MM 7070 mass apectrometer and a Cario Etbe Fractovap lines 2150 gas chromatograph. Most of the analytical work has been carried out with a packed OV-101 column or with a capillary column couted with OV-101. The carrier ges flow of helium protects the pyrolysis products ageinst oxidation (condicions similar to those of exrlier work (195s) where pyrolysis took place in nitrogen flowing through a quartz tube packed with quarzz chips). For the present pyrolysis work microgram quantities of material, adhering to a syringe. needle, were inserted into the temperakure-controlled microfurnace and a series of experiments was carried out at $500,550,600,650,700,750,800,825,850,875$, 900 and $950^{\circ} \mathrm{C}$. A great number of mas apeetsa were recorded on the basis of ges chromatograms obtained during the separation of the very complex mixture of pyrolysis products from each single experiment. The mass spectra were interpreted and in many cases compared with reference spectra of pure, commercially available compounds. A Hewlett-Packard 3380A integrator was used for the semi-quantitative determinations from the gas ebromatograms.

\section{RESULT'S AND DISCUSSION}

Pyrolysis of the organic material studied does not result in aromatization until the temperature exceeds 500 to $600^{\circ} \mathrm{C}$, starting with formation of benzene, toluene and rylenes and with increasing anounts produced at higher temperatures. At 2 first glance, the normal akanes seen to indicate that a special reaction occurs at 
the disintegration of the molecules since a series of normal alkenes $\left(C_{4}\right.$ to $C_{22}$ alkenes from $n$ - $C_{25}$ alkane) is produced at about $600^{\circ} \mathrm{C}$ (see Fig. 1). There is, however, a similar breakdown taking place for the isoprenoid substances neophytadiene and phytol starting at even lower temperature (about $500^{\circ} \mathrm{C}$ ).

The branched isoprenoid compounds produce unsaturated elements of alkene, alkadiene and alkatriene or unsaturated ring structures, particularly compounds formed by cleavage at the branched sites of neophytadiene (see Fig. 2 and Table 1) and of phytol, The clearest pattern of this is best studied by correlating the gas chromatograms from the pyrolysis of neophytadiene at $550^{\circ} \mathrm{C}$ with Table 1 . The phytol eliminates water forming branched diene molecules of the same molecular weight as that of neophytadiene. They react as neophytadiene does by breaking down to smaller unsaturated molecules, and they also react by forming aromatic hydrocarbons at generally lower temperatures than normal alkanes.

By inspection of Figures 1 and 2 it may be noticed that breakdown of the molecules leading to total disintegration and start of aromatization occurs at slightly lower temperature for the isoprenoid compound neophytadiene than for normal alkanes. Traces of benzene, toluene and xylenes were produced by pyrolysis of $n-\mathrm{C}_{25}$ alkane at $600^{\circ} \mathrm{C}$, whereas for neophytadiene pyrolysis at $550^{\circ} \mathrm{C}$ leads to formation of traces of the same aromatic hydrocarbons.

By study of the gas chromatogram from the pyrolysis of $n-\mathrm{C}_{25}$ alkane at $650^{\circ} \mathrm{C}$ (see Fig. 1) it is obvious that the decomposition has increased with only a faint alkene pattern left and with increased formation of other compounds, namely benzene and toluene and minor amounts of styrene and xylenes. At even higher temperatures $\left(700^{\circ} \mathrm{C}\right)$, the resulting pattern of the gas chromatogram almost entirely agrees with the aromatic hydrocarbon formation.

Figure 2 presents the gas chromatograms resulting from the pyrolysis of neophytadiene at 500,550 and $600^{\circ} \mathrm{C}$. At $500^{\circ} \mathrm{C}$ a slight disintegration takes place, strongly increasing by $550^{\circ} \mathrm{C}$, with a slight aromatization leading to the formation of benzene, toluene and xylenes, and with an even higher degree of aromatization occurring at $600^{\circ} \mathrm{C}$. The amounts of recovered neophytadiene, branched alkenes and alkadienes produced during pyrolysis are decreased at $600^{\circ} \mathrm{C}$ compared to $500^{\circ} \mathrm{C}$.

When phytol is pyrolysed at $550^{\circ} \mathrm{C}$ at least five phytadienes seem to be formed with different retention times in the gas chromatogram (all with the molecular weight of 278 corresponding to that of neophytadiene). The gas chromatogram moreover is very much like that of neophytadiene from the pyrolysis of this compound at $550^{\circ} \mathrm{C}$ with respect to the "fragments" appearing with increasing molecular weight up to the order of magnitude of $\mathrm{C}_{15} \mathrm{H}_{30}$, an isoprenoid alkene.

The possibility of thermal isomerization of neophytadiene during the smoking process is discussed by Alan Rodgman (14). We have not observed a preformation of isomeric phytadiene molecules by the pyrolysis of neophytadiene. It is thus more realistic to expect the formation of different phytadienes to be derived from phytol or phytol bound as an ester in the tobacco. This is supported by the fact that chlorophyll-bound phytol yields several phytadienes, when specific geological material containing chlorophylls is pyrolysed at $610^{\circ} \mathrm{C}$ (15).

The increase in temperature for normal alkane pyrolysis as well as for pyrolysis of the isoprenoid compound generally leads to more-condensed aromatic ring structures. However, a competition between decomposition and pyrosynthesis seems to occur (cf. the formation of benzo[ $a]$ pyrene at various temperatures) (16). A quite clear picture of the reactions which are taking place cannot be given at present as a series of radical mechanisms appears to be involved in the building of aromatic hydrocarbons at various temperatures. Furthermore, it seems likely that slightly different building blocks are taking part in the aromatization, when the compounds are produced either from normal alkanes or from isoprenoid compounds.

Aromatic hydrocarbons may react mutually, under suitable conditions. Two molecules of naphthalene may form perylene or benzofluoranthenes. Naphthalene plus benzene may give rise to fluoranthene $(16,17)$.

Although the attempts to correlate the formation of aromatic hydrocarbons quantitatively have not been very successful it is obvious from the integration of the gas chromatograms that benzene plus toluene constitute more than $50 \%$ of the total amount of aromatic hydrocarbons formed, when $n$-alkanes and branchedchain alkanes are pyrolysed at about $700^{\circ} \mathrm{C}$, in good agreement with the results obtained by Badger et al. (6, 18). The relative amount of styrene is about 9,25 and $32 \%$ when $n-\mathrm{C}_{25}$ alkane, neophytadiene, and phytol are pyrolyzed at $750^{\circ} \mathrm{C}$, respectively. At $825^{\circ} \mathrm{C}$ the corresponding values are 29,31 and $32 \%$, and at $900^{\circ} \mathrm{C}$ the pyrolysis yields 29,20 and $15 \%$, respectively, of the total amount of aromatic hydrocarbons formed. The relative percentage values were obtained by integration of the gas chromatograms. The observation that the aromatization processes are progressing at slightly lower energy with the branched-chain compounds than with the normal alkanes and that competition between aromatization and decomposition changes in favour of decomposition at increasing energy seems to agree well with the above-mentioned results.

Although there is a general increase in the amount of naphthalene formed with increasing temperature from 750 to $900^{\circ} \mathrm{C}$ in all three cases, and although generally with higher temperature more-condensed ring systems are formed, there is still an increasing amount of benzene from the pyrolysis of neophytadiene and phytol, whereas the relative amount of benzene decreases in the case of normal alkanes. The amount of toluene and xylenes is decreasing relatively with increasing pyrolysis temperature in all three cases ( $n$-alkanes, neophytadiene and phytol).

Whereas the formation of methyl-substituted aromatic 
hydrocarbons such as toluene, xylenes, methylnaphthalene and methylphenanthrene seems to decrease with increasing temperature, the formation of acenaphthene, acenaphthylene and similar products should perhaps not be neglected (1). After pyrolysis of all three compounds, n-alkanes and the two isoprenoids, at high temperatures $\left(700-950^{\circ} \mathrm{C}\right)$ the mass spectra reveal the presence of compounds with molecular weights of (190), 192, 202, 204, 216, 226, 228, (240), 242, 250, 252, 254, 276 and 278. The molecular weights of 202, 204, 226, 228 and 252 are all represented in more than one peak of the gas chromatogram, and thus they represent two or more compounds formed for each figure. Corresponding to the molecular weights of 226 and 228 several possible structures exist, however cyclopenta[ $c d]$ pyrene and 3,4-dihydrocyclopenta[ $c d]$ pyrene are compounds isolated (especially the cyclopenta[ $[c d]$ pyrene) from a selected carbon black in a relatively great amount (60 times as much as benzo[a]pyrene) (19).

Figure 3 shows possible structures for the molecular weights listed above; many other structures are possible, which is also indicated by the repeated appearance of certain molecular weight values obtained by mass spectrometry (GC-MS in high-temperature pyrolysis experiments). Structures I and II, characterized in previous research (1953-1956), may be the basis of the development of fused ring structures at increasing temperature.

Benzo[a]pyrene and benzo[e]pyrene are frequently reported to be present in tobacco smoke and they could possibly give rise to the formation of compounds analogous to cyclopenta[ $c d$ ] pyrene and a corresponding dihydro compound, but derived from the benzopyrenes. The molecular weights of such compounds would be 276 and 278 , respectively, in agreement with those recorded in our pyrolysis experiments at high temperature $\left(800-900^{\circ} \mathrm{C}\right)$ with $n$-alkane, with neophytadiene, and also with phytol.

Doubly charged ions in the mass spectra are very informative in the interpretation of the spectra of aromatic hydrocarbons. Some of the spectra contain several molecular weight figures. Characteristic mass spectral patterns correspond to the molecular weight recordings of stable aromatic structures. Each molecular weight figure may represent more than one structure. It may therefore be a future challenge to study on a greater scale pyrolysis products in detail, when pyrolysis of specific compounds is performed at high temperature $\left(900-1000^{\circ} \mathrm{C}\right)$.

In Table 2 is recorded a typical list of molecular weights corresponding to pyrolysis products as they appear in our high-temperature experiments (700$950^{\circ} \mathrm{C}$ ) with $n$-alkanes and isoprenoid compounds and as they are known from tobacco smoke and from various pyrolysis studies at high temperatures (800$\left.950^{\circ} \mathrm{C}\right)(20,21)$ based on MS data. Pyrolysis of toluene at 850 and $950^{\circ} \mathrm{C}$ has revealed that a certain degree of decomposition occurs leading to the formation of benzene, indene, naphthalene, acenaphthene, acenaphthy- lene, fluorene and many other aromatic substances, which are apparently the same as those produced from $n$-alkanes and isoprenoid compounds by pyrolysis. The major part of the toluene came out unchanged under the present conditions which were not ideal as the toluene (being a liquid) had to be injected into the pyrolysis unit.

Similarly acenaphthylene, which is another compound abundantly formed by pyrolysis of $n$-alkanes and isoprenoid compounds at high temperature $(2,11,18)$, was pyrolysed. The pyrolysis products from acenaphthylene resulted in a similar series of compounds to those produced by the aliphatic hydrocarbons, apparently showing a cleavage of the bonds in the five-carbon ring of acenaphthylene.

The pyrolysis experiments with toluene and acenaphthylene were carried out in order to study the further decomposition and pyrosynthesis of aromatic hydrocarbons which are typical examples of aromatics formed by pyrolysis and pyrosynthesis of $n$-alkanes and branched-chain hydrocarbons at high temperature $(6$, 18).

\section{REFERENCES}

1. Lam, J.: Isolation and identification of 3,4-benzpyrene, chrysene, and a number of other aromatic hydrocarbons in the pyrolysis products from dicetyl; Acta Pathol. Microbiol. Scand. 39 (1956) 198-206.

2. Lam, J.: Determination of 3,4-benzpyrene and other aromatic compounds formed by pyrolysis of aliphatic tobacco hydrocarbons; Acta Pathol. Microbiol. Scand. 39 (1956) 207-210.

3. Lam, J.: Measuring temperature during combustion in cigarettes, cigarillos, cigars, and pipes; Acta Pathol, Microbiol. Scand. 36 (1955) 503-510.

4. Wynder, E. L., G. F. Wright and J. Lam: A study of tobacco carcinogenesis, V. The role of pyrolysis; Cancer 11 (1958) 1140-1148.

5. Wynder, E. L., G. F. Wright and J. Lam: A study of tobacco carcinogenesis, VI. The role of precursors; Cancer 12 (1959) 1073-1078.

6. Badger, G. M., J. K. Donelly and T. M. Spotswood: The formation of aromatic hydrocarbons at high temperatures, XV. The pyrolysis of 2,2,4-trimethylpentane; Aust. J. Chem. 15 (1962) 605-615.

7. Badger, G. M., R. W. L. Kimber and J. Novotny: The formation of aromatic hydrocarbons at high temperatures, XXI. The pyrolysis of $n$-butylbenzene over a range of temperatures from 300 to $900^{\circ} \mathrm{C}$ at $50^{\circ} \mathrm{C}$ intervals; Aust. J. Chem. 17 (1964) $778-786$.

8. Jenkins, R. W., Jr., R. H. Newman, M. D. Edmonds and T. S. Osdene: Cigarette smoke formation studies, III. The contribution of dotriacontane to the benzo[ $a]$ pyrene content of smoke; Beitr. Tabakforsch. 7 (1973) 154-157. 
9. Schlotzhauer, W. S., I. Schmeltz and S: F. Osman: Evidence for the origin of monoalkenes in cigarette smoke; Chem. Ind. (Lond.) 1970, 1377-1378.

10. Schmeltz, I., and D. Hoffmann: Chemical studies on tobacco smoke, XXXVIII. The physicochemical nature of cigarette smoke; Proceedings of the 3rd World Conference on Smoking and Health (Volume I), New York City, 1975; U.S. Department of Health, Education, and Welfare, DHEW Publication No. (NIH) 76-1221, pp. 13-34.

11. Schlotzhauer, W. S., R. F. Severson, O. T. Chortyk, R. F. Arrendale and H. C. Higman: Pyrolytic formation of polynuclear aromatic hydrocarbons from petroleum ether extractable constituents of the flue-cured tobacco leaf; J. Agric. Food Chem. 24 (1976) 992-997.

12. Johnstone, R. A. W., and J. R. Plimmer: The chemical constituents of tobacco and tobacco smoke; Chem. Rev. 59 (1959) 885-936.

13. Larter, S. R., H. Solli and A. G. Douglas: Analysis of kerogens by pyrolysis - gas chromatography mass spectrometry using selective ion detection; J. Chromatogr. 167 (1978) 421-431.

14. Rodgman, A.: Composition of cigarette smoke, III. Phytadienes; J. Org. Chem. 24 (1959) 1916-1924.

15. VanDeMeent, D., J. W. DeLeeuw and P. A. Schenck: Origin of unsaturated isoprenoid hydrocarbons in pyrolysates of suspended matter and surface sediments; Advances in Organic Geochemistry $1979,469-474$.

16. Lam, J.: Some aspects of the mechanism of the high temperature pyrolysis of aromatic and aliphatic hydrocarbons; Acta Pathol. Microbiol. Scand. 45 (1959) 237-242.
17. Badger, G. M., S. D. Jolad and T. M. Spotswood: The formation of aromatic hydrocarbons at high temperatures, XX. The pyrolysis of $\left[1-{ }^{14} \mathrm{C}\right]-$ naphthalene; Aust. J. Chem. 17 (1964) 771-777.

18. Badger, G. M., and J. Novotny: The formation of aromatic hydrocarbons at high temperatures, XVIII. The pyrolysis of $n$-decane; Aust. J. Chem. 16 (1963) 613-622.

19. Wallcave, L., D. L. Nagel, J. W. Smith and R. D. Waniska: Two pyrene derivatives of widespread environmental distribution - Cyclopenta[cd] pyrene and acepyrene; Environ. Sci. Technol. 9 (1975) $143-145$.

20. Snook, M. E., R. F. Severson, R. F. Arrendale, H. C. Higman and $O$. T. Chortyk: The identification of high molecular weight polynuclear aromatic hydrocarbons in a biologically active fraction of cigarette smoke condensate; Beitr. Tabakforsch. 9 (1977) 79-101.

21. Tintel, C., J. Cornelisse and J. Lugtenburg: Convenient synthesis of cyclopenta[ $c d]$ pyrene and 3,4-dihydrocyclopenta[ $c d]$ pyrene, The reactivity of the pyrene dianion; Recueil (Journal of the Royal Netherlands Chemical Society) 102/1 (1983) 1420.

Authors' address:

Department of Organic Chemistry,

Chemical Institute,

University of Aarbus,

DK-8000 Aarhus C, Denmark. 
Table 1.

Pyrolysis of neophytadlene at $550^{\circ} \mathrm{C}$.

\begin{tabular}{|c|c|c|c|}
\hline $\begin{array}{l}\text { GC } \\
\text { peak } \\
\text { regis- } \\
\text { tration }\end{array}$ & $\begin{array}{l}\text { Molecular } \\
\text { weight (MS) }\end{array}$ & $\begin{array}{c}\text { Molecular } \\
\text { formula }\end{array}$ & $\begin{array}{c}\text { Number of } \\
\text { double bonds } \\
\text { or } \\
\text { ring equivalents * }\end{array}$ \\
\hline \multirow[t]{2}{*}{1} & 56 & $\mathrm{C}_{4} \mathrm{H}_{8}$ & 1 \\
\hline & 70 & $\mathrm{C}_{5} \mathrm{H}_{10}$ & 1 \\
\hline \multirow[t]{2}{*}{2} & 56 & $\mathrm{C}_{4} \mathrm{H}_{8}$ & 1 \\
\hline & 70 & $\mathrm{C}_{5} \mathrm{H}_{10}$ & 1 \\
\hline \multirow[t]{2}{*}{3} & 68 & $\mathrm{C}_{5} \mathrm{H}_{8}$ & 2 (isoprene?) \\
\hline & 70 & $\mathrm{C}_{5} \mathrm{H}_{10}$ & 1 \\
\hline \multirow[t]{2}{*}{4} & 82 & $\mathrm{C}_{6} \mathrm{H}_{10}$ & 2 \\
\hline & 84 & $\mathrm{C}_{6} \mathrm{H}_{12}$ & 1 \\
\hline \multirow[t]{3}{*}{5} & 78 & $\mathrm{C}_{8} \mathrm{H}_{8}$ & benzene \\
\hline & 80 & $\mathrm{C}_{8} \mathrm{H}_{8}$ & 3 \\
\hline & 98 & $\mathrm{C}_{7} \mathrm{H}_{14}$ & 1 \\
\hline \multirow[t]{2}{*}{6} & 96 & $\mathrm{C}_{7} \mathrm{H}_{12}$ & 2 \\
\hline & 98 & $\mathrm{C}_{7} \mathrm{H}_{14}$ & 1 \\
\hline \multirow[t]{4}{*}{7} & 92 & $\mathrm{C}_{7} \mathrm{H}_{8}$ & toluene \\
\hline & 94 & $\mathrm{C}_{7} \mathrm{H}_{10}$ & 3 \\
\hline & 96 & $\mathrm{C}_{7} \mathrm{H}_{12}^{\prime}$ & $\because 2$ \\
\hline & 112 & $\mathrm{C}_{8} \mathrm{H}_{16}$ & 1 \\
\hline \multirow[t]{3}{*}{8} & 92 & $\mathrm{C}_{7} \mathrm{H}_{8}$ & toluene \\
\hline & 94 & $\mathrm{C}_{7} \mathrm{H}_{10}$ & 3 \\
\hline & 112 & $\mathrm{C}_{8} \mathrm{H}_{16}$ & 1 \\
\hline \multirow[t]{4}{*}{9} & 106 & $\mathrm{C}_{8} \mathrm{H}_{10}$ & xylene \\
\hline & 108 & $\mathrm{C}_{8} \mathrm{H}_{12}$ & 3 \\
\hline & 110 & $\mathrm{C}_{8} \mathrm{H}_{14}$ & 2 \\
\hline & 126 & $\mathrm{C}_{9} \mathrm{H}_{18}$ & 1 \\
\hline \multirow[t]{3}{*}{10} & 122 & $\mathrm{C}_{9} \mathrm{H}_{14}$ & 3 \\
\hline & 124 & $\mathrm{C}_{9} \mathrm{H}_{18}$ & 2 \\
\hline & 140 & $\mathrm{C}_{10} \mathrm{H}_{20}$ & 1 \\
\hline \multirow[t]{3}{*}{11} & 136 & $\mathrm{C}_{10} \mathrm{H}_{16}$ & 3 \\
\hline & 138 & $\mathrm{C}_{10} \mathrm{H}_{18}$ & 2 \\
\hline & 154 & $\mathrm{C}_{11} \mathrm{H}_{22}$ & 1 \\
\hline 12 & 154 & $\mathrm{C}_{11} \mathrm{H}_{22}$ & 1 \\
\hline 14 & 182 & $\mathrm{C}_{13} \mathrm{H}_{28}$ & 1 \\
\hline 15 & 196 & $\mathrm{C}_{14} \mathrm{H}_{28}$ & 1 \\
\hline $16-18$ & 210 & $\mathrm{C}_{15} \mathrm{H}_{30}$ & 1 \\
\hline $20-22$ & 278 & $\mathrm{C}_{20} \mathrm{H}_{38}$ & 2 (neophytadiene) \\
\hline
\end{tabular}

"Where aromatic compounds are formed the name or type is indicated.
Table 2.

Compounds assumed to be obtained after high-temperature pyrolysis $\left(700-950^{\circ} \mathrm{C}\right)$ of n-alkanes and lsoprenolds.

\begin{tabular}{|c|c|c|}
\hline $\begin{array}{l}\text { Molecular } \\
\text { weight }\end{array}$ & Compound & $\begin{array}{c}\text { Molecular } \\
\text { formula }\end{array}$ \\
\hline 66 & cyclopentadiene? & $\mathrm{C}_{6} \mathrm{H}_{6}$ \\
\hline 78 & benzene & $\mathrm{C}_{6} \mathrm{H}_{8}$ \\
\hline 92 & toluene & $\mathrm{C}_{7} \mathrm{H}_{8}$ \\
\hline 102 & phenylacetylene & $\mathrm{C}_{8} \mathrm{H}_{6}$ \\
\hline 104 & styrene & $\mathrm{C}_{8} \mathrm{H}_{8}$ \\
\hline 118 & indane & $\mathrm{C}_{9} \mathrm{H}_{10}$ \\
\hline 116 & indene & $\mathrm{C}_{8} \mathrm{H}_{8}$ \\
\hline 130 & dihydronaphthalene? & $\mathrm{C}_{10} \mathrm{H}_{10}$ \\
\hline 128 & naphthalene & $\mathrm{C}_{10} \mathrm{H}_{8}$ \\
\hline 142 & $\beta$ - and $\alpha$-methylnaphthalenes & $\mathrm{C}_{11} \mathrm{H}_{10}$ \\
\hline 154 & acenaphthene & $\mathrm{C}_{12} \mathrm{H}_{10}$ \\
\hline 152 & acenaphthylene & $\mathrm{C}_{12} \mathrm{H}_{8}$ \\
\hline 166 & fluorene & $\mathrm{C}_{13} \mathrm{H}_{10}$ \\
\hline 180 & dihydrophenanthrene? & $\mathrm{C}_{14} \mathrm{H}_{12}$ \\
\hline 178 & phenanthrene + anthracene & $\mathrm{C}_{14} \mathrm{H}_{10}$ \\
\hline $192^{*}$ & & $\mathrm{C}_{15} \mathrm{H}_{12}$ \\
\hline $190^{*}$ & & $\mathrm{C}_{15} \mathrm{H}_{10}$ \\
\hline $204^{*}$ & & $\mathrm{C}_{18} \mathrm{H}_{12}$ \\
\hline $202^{*}$ & & $\mathrm{C}_{10} \mathrm{H}_{10}$ \\
\hline $216^{*}$ & & $\mathrm{C}_{17} \mathrm{H}_{12}$ \\
\hline $228^{*}$ & & $\mathrm{C}_{18} \mathrm{H}_{12}$ \\
\hline $226^{*}$ & & $\mathrm{C}_{18} \mathrm{H}_{10}$ \\
\hline $242^{*}$ & & $\mathrm{C}_{19} \mathrm{H}_{14}$ \\
\hline $240^{*}$ & & $\mathrm{C}_{19} \mathrm{H}_{12}$ \\
\hline $250^{*}$ & & $\mathrm{C}_{20} \mathrm{H}_{10}$ \\
\hline $252^{*}$ & & $\mathrm{C}_{20} \mathrm{H}_{12}$ \\
\hline $254^{*}$ & & $\mathrm{C}_{20} \mathrm{H}_{14}$ \\
\hline $276^{*}$ & & $\mathrm{C}_{22} \mathrm{H}_{12}$ \\
\hline - $278^{*}$ & & $\mathrm{C}_{22} \mathrm{H}_{14}$ \\
\hline
\end{tabular}




\section{Figure 1.}

Gas chromatograms after pyrolysis of $n-C_{25}$ alkane at different temperatures."
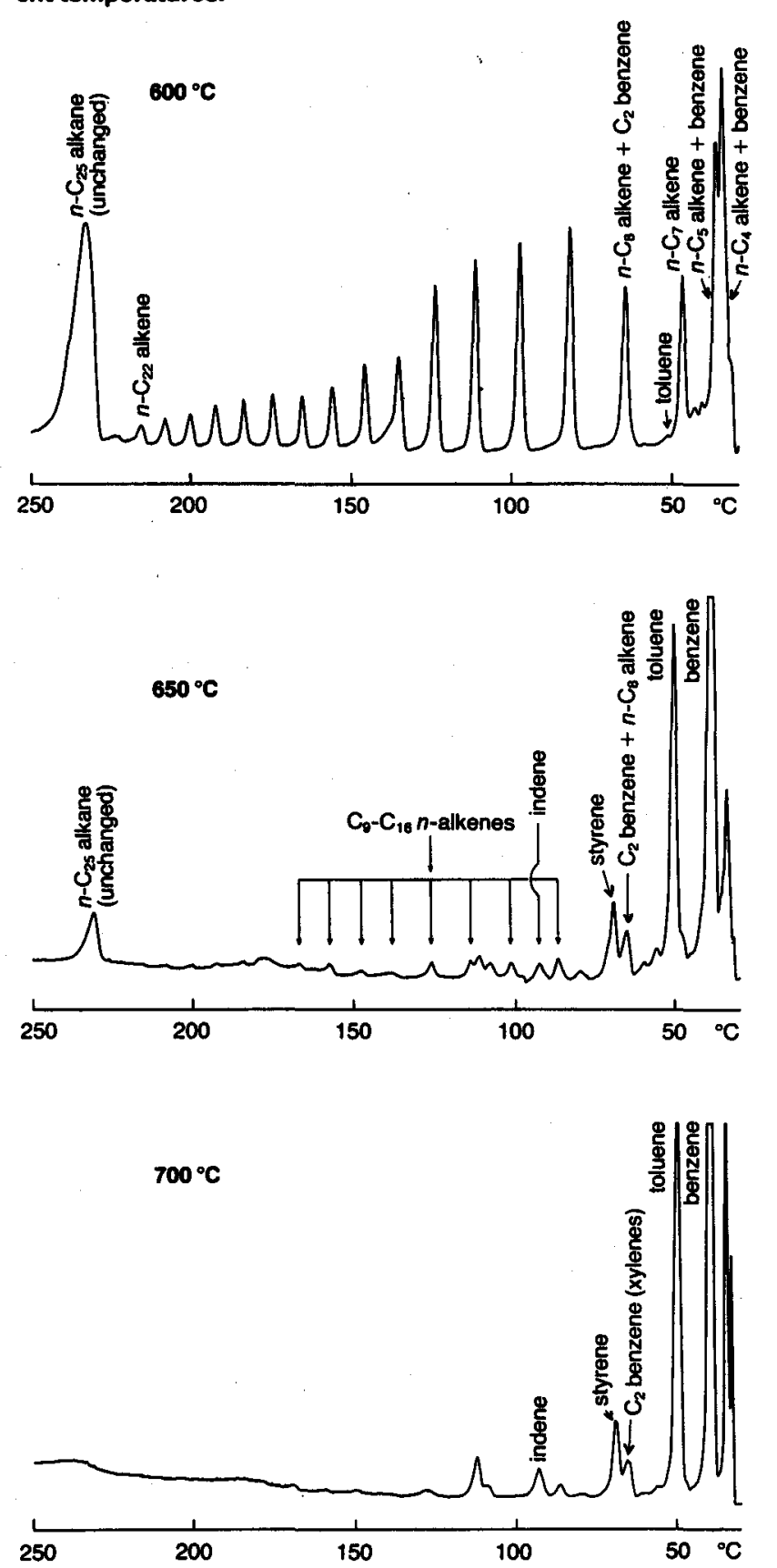

Figure 2.

Gas chromatograms after pyrolysls of neophytadiene at different temperatures."

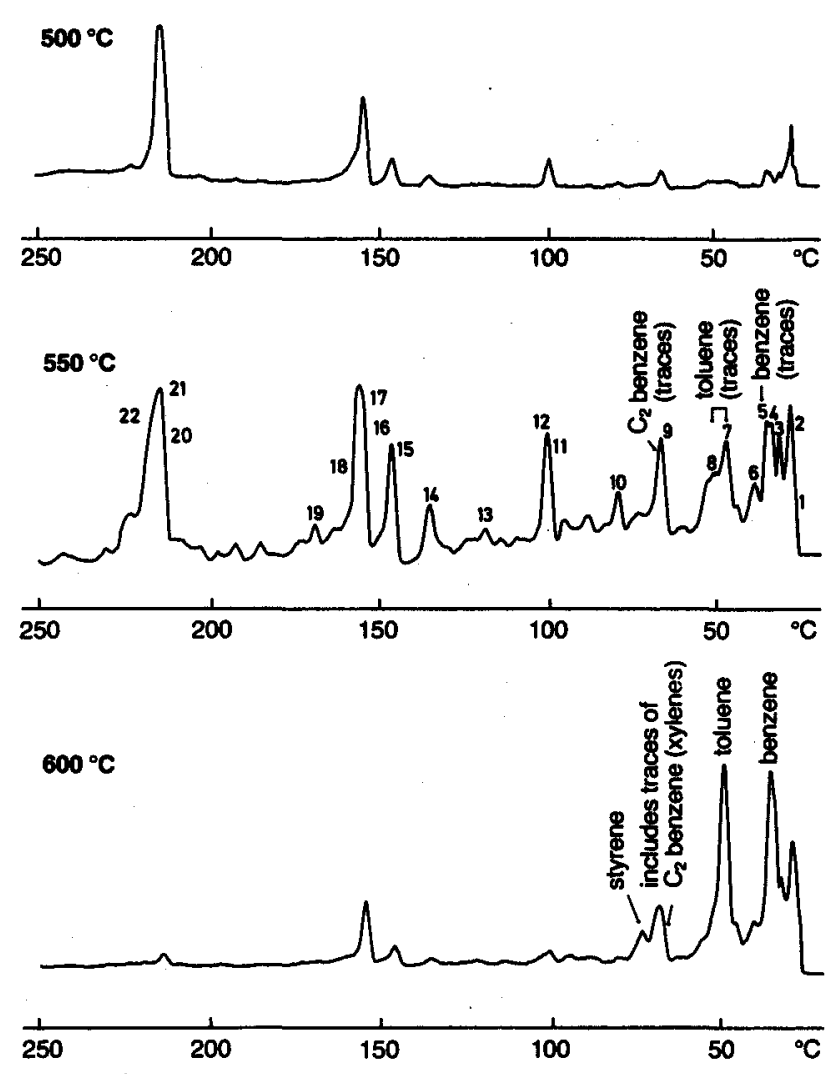

The separation of pyrolysis products on OV-101 is based on program-
ming from $30^{\circ} \mathrm{C}$ to $250^{\circ} \mathrm{C}$ with an increase in temperature of $4^{\circ} / \mathrm{min}$. 
Figure 3.

Possible structural formulae for the molecular weights found after pyrolys ls of n-alkanes and lsoprenolds.

\begin{tabular}{c|c|c|c|c}
\hline $\begin{array}{c}\text { Compound } \\
\text { No. }\end{array}$ & $\begin{array}{c}\text { Molecular } \\
\text { weight }\end{array}$ & $\begin{array}{c}\text { Molecular } \\
\text { formula }\end{array}$ & Structural formula & References \\
\hline
\end{tabular}

1

152

II

154

166

IV

190

192

VI

202

VII

204

216

IX

226
$\mathrm{C}_{12} \mathrm{H}_{8}$

$\mathrm{C}_{12} \mathrm{H}_{10}$

$\mathrm{C}_{13} \mathrm{H}_{10}$

$\mathrm{C}_{15} \mathrm{H}_{10}$

$\mathrm{C}_{15} \mathrm{H}_{12}$

$\mathrm{C}_{18} \mathrm{H}_{10}$

$\mathrm{C}_{16} \mathrm{H}_{12}$

$\mathrm{C}_{17} \mathrm{H}_{12}$

$\mathrm{C}_{18} \mathrm{H}_{10}$<smiles></smiles>

Acenaphthylene<smiles>c1cc2c3c(cccc3c1)CC2</smiles>

Acenaphthene
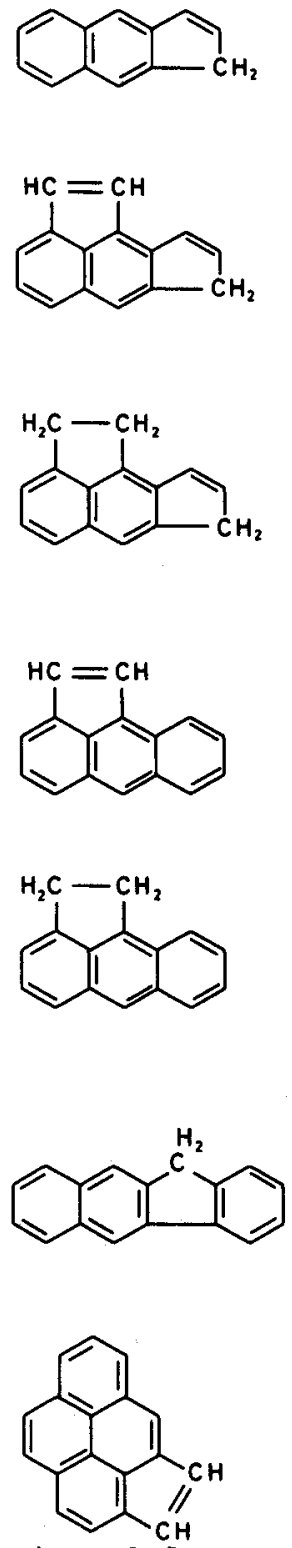

cyclopenta[cd]pyrene
1

1

8 
Figure 3 (contd.).

\begin{tabular}{c|c|c|c|c|c}
\hline $\begin{array}{c}\text { Compound } \\
\text { No. }\end{array}$ & $\begin{array}{c}\text { Molecular } \\
\text { weight }\end{array}$ & $\begin{array}{c}\text { Molecular } \\
\text { formula }\end{array}$ & Structural formula & References \\
\hline
\end{tabular}

$x$

228

XI

240

XII

242

XIII

250

XIV

252

XV

254

XVI

252

XVII
$\mathrm{C}_{18} \mathrm{H}_{12}$

$\mathrm{C}_{18} \mathrm{H}_{12}$

$\mathrm{C}_{19} \mathrm{H}_{14}$

$\mathrm{C}_{20} \mathrm{H}_{10}$

$\mathrm{C}_{20} \mathrm{H}_{12}$

$\mathrm{C}_{20} \mathrm{H}_{14}$

$\mathrm{C}_{20} \mathrm{H}_{12}$

$\mathrm{C}_{20} \mathrm{H}_{12}$<smiles></smiles>

19,21

3,4-dihydrocyclopenta[cd]pyrene<smiles>C1=Cc2c3c(cc4cccc1c24)-c1ccccc1C3</smiles><smiles>c1ccc2c(c1)Cc1c-2cc2cccc3c2c1CC3</smiles><smiles></smiles><smiles></smiles><smiles></smiles><smiles>c1ccc2c(c1)cc1ccc3cccc4ccc2c1c34</smiles>

Benzo[a]pyrene

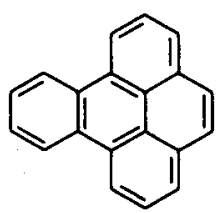

Benzo[e]pyrene

9 